\title{
COVENANTS IN A LEASE WHICH RUN WITH THE LAND
}

\author{
EDWIN H. AвBot, JR. \\ Assistant Attorney-General, Massachusetts
}

I

PRELIMINARY

The purpose of this article is to consider anew the tests which determine whether a covenant in a lease will run with the land. The subject is by no means novel. The leading case was decided in $1583,{ }^{1}$ if the resolutions promulgated in Spencer's Case can be considered a decision. But in view of the seeming conflict between the first and second reso-

${ }^{2}$ Spencer's Case ( $5583, \mathrm{~K} . \mathrm{B}$. ) 5iCo. Rep. I6a. The first two resolutions read as follows:

I. When the covenant extends to a thing in esse, parcel of the demise, the thing to be dono by force of the covenant is quodammodo annexed and appurtenant to the thing demised, and shall go with the land, and shall bind the assignee although he be not bound by express words: but when the covenant extends to a thing which is not in being at the time of the demise made, it cannot be appurtenant or annexed to the thing which hath no being: as if the lessee covenants to repair the houses demised to him during the term, that is parcel of the contract, and extends to the support of the thing demised, and therefore is quodammodo annexed appurtenant to houses, and shall bind the assignee although he be not bound expressly by the covenant: but in the case at bar, the covenant concerns a thing which was not in esse at the time of the demise made, but to be newly built after, and therefore shall bind the covenantor, his executors or administrators, and not the assignee, for the law will not annex the covenant to a thing which hath no being.

2. It was resolved that in this case, if the lessee had covenanted for him and his assigns, that they would make a new wall upon some part of the thing demised, that for as much as it is to be done upon the land demised, that it should bind the assignee; for although the covenant doth extend to a thing to be newly made, yet it is to be made upon the thing demised, and the assignee is to take the benefit of it, and therefore shall bind the assignee by express words. So on the other side, if a warranty be made to one, his heirs and assigns, by express words, the assignee shall take benefit of it, and shall havo a Warrantia Chartae, F. N. B. 135, \& 9 E. 2. Garr de Charters 30,36 E. 3. Garr. I, 4 H. 8. Dyer I. But although the covenant be for him and his assigns, yet if the thing to be done be merely collateral to the land, and doth not touch or concern the thing demised in any sort, there the assignee shall not be charged. As if the lessee covenants for him and his assigns to build a houso upon the land of the lessor which is no parcel of the demise, or to pay any collateral sum to the lessor, or to a stranger, it shall not bind the assignee, because it is merely collateral, and in no manner touches or concerns the thing that was demised, or that is assigned over; and therefore in such case the assignee of the thing demised cannot be charged with it, no more than any other stranger. 
lutions of that case, the doubt as to what the actual decision was, ${ }^{2}$ and the conflict which has arisen among cases which purport to follow it, it may not be wholly without worth to see whether later decisions do not enable us to reformulate the tests somewhat more clearly.

The first question is as to just what we mean by a covenant which runs with the land. It is a covenant which is so attached to the land, that the right to enforce it, or the obligation to perform it, passes with the estate conveyed, as an incident of ownership.

There is special necessity for permitting the creation of such covenants in leases. Many of the incidents of a leasehold estate and reversion are executory covenants. At common law one who is not a party to a covenant can neither sue ${ }^{3}$ nor be sued $d^{4}$ directly upon it. The parties to the covenants in a lease are the original lessor and the original lessee. If either convey his estate, his grantee can neither sue nor be sued as . a party to the covenant in the lease, unless such covenants pass as an incident of the estate conveyed. But a large part of the value of the lease would disappear unless the direct relation of landlord and tenant be preserved, as between the assigns of the original parties to the lease, by giving to each a remedy upon, and imposing on each an obligation under, the covenants of the lease. To meet this necessity the Statute of $3^{2}$ Hen. VIII, c. 34, was passed in I540. This statute has been held to be part of the common law in the great majority of our states. ${ }^{5}$

The point that privity of estate is the key to the situation is emphasized by the circumstances under which St. 32 Hen. VIII, c. 34, was enacted. After Henry VIII broke with the Pope he caused the lands of many monasteries to be forefeited to the Crown and subsequently granted them to others. Many of these lands were under lease. By reason of the forfeiture it was impossible to work out even the semblance of an assignment by the lessors of the covenants contained in the leases.

${ }^{2}$ See Purvis v. Shuman (I9I6) 273 Ill. 286, 294, II2 N. E. 679, 682; Sexauer v. Wilson (1907) ז36 Iowa, 357, 362, $\mathrm{II}_{3} \mathrm{~N}_{2}$ W. 94I, 943; Masury v. Southworth (I859) 9 Ohio St. 340, 350; Bald Eagle Ry. v. Nittany etc. Ry. (I895) I7I Pa. 284, 294-5, 33 Atl. 239, 24I.

${ }^{3}$ Sanders v. Filley (1832, Mass.) I2 Pick. 554; Johnson v. Foster (I846, Mass.) 12 Met. 167; Millard v. Baldwin (1855, Mass.) 3 Gray, 484; Flynn v. North American L. Ins. Co. (1874) II5 Mass. 449; Thomas v. Hayward (1869) L. R. ${ }_{4}$ Exch. 3II; Tallman v. Coffin (1850) 4 N. Y. I34; Hansen v. Meyer (1876) 8I Ill. 321 .

"Boyden v. Hill (Ig08) I98 Mass. 477, 85 N. E. 413; New England etc. Co. v. Rockport Granite Co. (I889) I49 Mass. 38I, 21 N. E. 947.

${ }^{5}$ Sims, Real Covenants (Igor) 73 et seq.; Scott v. Lunt (I833, U. S.) 7 Pet. 596, 606; Sheets v. Selden (1864, U. S.) 2 Wall. 177, 189; Howland v. Coffin (183I, Mass.) I2 Pick. I25, 126; Patten v. Deshon (I854, Mass.) I Gray, 325, 326; Carleton v. Bird (1900) $94 \mathrm{Me}$. I82, I9I, 47 Atl. I54, I56 (semble). In some states it has been in substance re-enacted. See Sims, loc. cit. See note 9 infra. 
Consequently, the grantees of the Crown received lands subject to leases the covenants of which they could not enforce against the lessees because they (the grantees) were not parties thereto. ${ }^{8}$ Some remedy was necessary. That remedy was.St. (I540) 32 Hen. VIII, c. 34, which provided, in substance, that the grantees of the King and the heirs, executors, successors and assigns of the lessors, should have the same remedies against the lessees, their executors, administrators and assigns, as the lessors would have had, and conversely that the lessees, their executors, administrators and assigns, should have the-same remedies against the grantees of the King and the lessors, their heirs, successors and assigns, as the lessees would have had. Thus St. 32 Hen. VIII, c. 34 , created, as between lessors and lessees, and their respective heirs, executors, administrators, successors and assigns, an exception to the rule that one who is not a party to a covenant can neither sue nor be sued upon it. Yet it did not create privity of contract between either the lessor or the lessee and an assign of either. The mutuality of remedy conferred by the statute rests upon privity of estate ${ }^{\tau}$ and continues only so long as such privity exists. ${ }^{8}$ Thus the need for the relief given by the statute arose out of privity of estate, where privity of contract was lacking, and consequently is confined to the case where privity of estate exists.

It is not without significance that a somewhat similar remedy has been worked out, without the aid of the statute, in two cases where a similar need has arisen. St. 32 Hen. VIII, c. 34, applies to leases only. ${ }^{\circ}$ It does not apply to deeds. Yet the doctrine of covenants running with the land applies to deeds, ${ }^{10}$ provided that privity of estate be established, ${ }^{11}$ and the intention that the covenant shall run is sufficiently declared. ${ }^{12}$ So also where the owner of a business and good will conveys it to another, with a covenant or agreement on his own part not to

\footnotetext{
'See recitals in (I540) 32 Hen. VIII, c. 34 . The statute is reprinted in 2 Gray, Cases on Real Property (2d ed. I905) 32I.

"Privity of estate is defined as "mutual or successive relationship to the same right of property." Bigelow v. Old Dominion Copper Co. (I9I2) 225 U. S. III, I29, 32 Sup. Ct. 64r, 643.

${ }^{8}$ Donaldson v. Strong (I907) 195 Mass. 429, 8I N. E. 267; Mason v. Smith (I88I) I3I Mass. 5Io.

'It is in force in most of the states of the union either as part of the common law, or by re-enactment. Sims, op. cit., 73 et seq. See also Howland v. Coffin, supra note 5; Patten v. Deshon, supra note 5; Carleton v. Bird, supra note 5; Scott v. Lunt, supra note 5; Sheets v. Selden, supra note 5. It is not in force in Ohio but another statute is held to give the same remedy. Masury $v$. Southworth (1859) 9 Ohio St. 340; Broadwell v. Banks (I905, C. C. D. Mo.) I34 Fed. 470,474 .

${ }^{10}$ Pakenham's Case (1368) Y. B. 42 Edw. III, p. 3, pl. I4; Anonymons (I582) Moore I79, pl. 3 ; Morse v. Aldrich (I837, Mass.) r9 Pick. 449 ; I5 C. J. I24I.

"1. Plymouth v. Carver (I834, Mass.) I6 Pick. I83; I5 C. J. I238.

${ }^{12}$ Savage v. Mason (1849, Mass.) 3 Cush. 500; I5 C. J. I24I.
} 
establish a competing business to the detriment of the good will so conveyed, both the good will and the covenant or agreement for its protection are in a sense appurtenant to the business conveyed, and a subsequent assignee of the business and good will may enforce the agreement ${ }^{13}$ at least in equity. In other words, the covenant or agreement $t^{14}$ becomes an incident of the business and, in equity at least, in effect runs with it. ${ }^{15}$ Thus entirely apart from the provisions of $3^{2} \mathrm{Hen}$. VIII, c. 34 , which applies neither to deeds nor to convenants or agreements for the protection of the good will of a business conveyed, we find that the grantee or assignee has, in equity at least, a remedy upon or an obligation under a covenant or contract to which he is not a party because it touches and concerns property which has passed to him. In both instances a chose in action so inheres in the property that ownership of the property carries with it a remedy upon this executory incident thereof ${ }^{16}$ in spite of the rule that title to a non-negotiable chose in action cannot pass by assignment, and the further rule that only parties to an agreement can sue or be sued upon it.

Although at first sight there is a seeming similarity between the running of a covenant and an assignment of it, the two situations are entirely distinct. An assignment of the covenant carries a right to sue in the name of the assignor, or of his personal representative if he be dead. ${ }^{17}$ It confers the benefit of the covenant on the assignee without the burden, although of course the assignee cannot recover without proof that the obligations of the assignor have been performed. The

${ }^{13}$ California Stean Nav. Co. v. Wright (1865) 6 Calif. 258; Swanson v. Kirby (1896) $98 \mathrm{Ga} .586,26 \mathrm{~S}$. E. 7I; Hedge v. Lowe (1877) 47 Iowa, I37; Klein v. Buck (I895) 73 Miss. I33, I8 So. 891 ; Palmer v. Toms (I897) 96 Wis. 367, 71 N. W. 654 ; Elwes v. Crofts (1850) xo C. B. $24 \mathrm{I}$; Jenkins v. Eliot (1906) I92 Mass. 474, 78 N. E. 43I; Foss v. Roby (rgo7) I95 Mass. 292, 8I N. E. I99; Myott v. Greer (Igro) 204 Mass. 389, 90 N. E. 895; see also Old Corner Book Store v. Upham (1907) 194 Mass. 10I, 80 N. E. 228; 20 Cyc. I28I, note 36.

${ }^{1 *}$ In this case the obligation need not be under seal, although in the case of land nothing except a covenant will run. Standen v. Chrismas (1847) 1o Q. B. 135. There is conflict whether a stipulation which purports to bind the grantee of a deed poll (who seals nothing) can be deemed a covenant by him which will run. Kennedy $v$. Owen (I884) x36 Mass. I99 and cases cited.

${ }^{15}$ See authorities note 13 supra.

${ }^{16}$ It must be noted, however, that, in the case of covenants running with the land, a stranger to the title cannot attach an incident to the property. Thus even though the covenant of a stranger touches and concerns the land, it cannot run for want of privity of estate. See note II supra.

"Thompson v. Rose (1828, N. Y.) 8 Cow. 266; Grover v. Grover (1837, Mass.) 24 Pick. 26I; Foss v. Lowell, etc., Sav. Bank (1873) III Mass. 285; Pierce v. Boston Sav. Bank (I880) I29 Mass. 425. Statutes in many states now perrmit or even require that the suit shall be brought in the name of the real party in interest, but this is merely a change in form and the defendant may maintain against the assignee any defence which he could maintain against the assignor. See Rogers v. Abbot (19I0) 206 Mass. 270, 92 N. E. 472. 
right of the assignee, therefore, rests upon the privity of contract existing between the assignor and the defendant, and is derivative, not direct. But where the covenant runs by reason of privity of estate, transfer of the estate carries with it the benefit and the burden of the covenant, ${ }^{18}$ even though it does not relieve the original covenantor of the burden imposed upon him by privity of contract.19 Moveover, as we have already seen, the remedy is direct, not derivative. The difference, therefore, is that in the case of an assignment we have a derivative remedy resting upon privity of contract, while in the case of the running of a covenant we have a direct remedy resting upon privity of estate, because the covenant is appurtenant to the estate.

Another class of rights, which superficially resembles covenants which run with the land, is sometimes confused with them. The Chancellor will often compel one who takes property with notice of an equity to respect that equity even though no action at law would lie as against this particular defendant to recover damages. In this class fall a large class of equitable restrictions upon the use of real estate, which may be enforced against those who take with notice of the covenant, even though they do not run with the land. ${ }^{20}$ A true covenant which runs with the land, being an incident thereof and appurtenant thereto, would bind even a purchaser for value and without notice of the covenant. So, also, if A, owning real estate or an interest therein, makes a contract in respect of it, and thereafter disposes of it to one who takes with notice, equity may still decree specific performance, not only against the grantor, but likewise against the grantee with notice. ${ }^{21}$ But this class of cases rests upon the equitable principle of privity of conscience, not upon the legal principle of privity of estate.

To sum up, therefore, a true covenant which "runs" with the land "runs" by reason of privity of estate. It must be distinguished from assignments, which rest upon a derivative privity of contract, and the equitable principle, which permits enforcement of a lawful contract

\footnotetext{
${ }^{13}$ Northern T. Co. v. Snyder (I896, C. C. A. 7 th) 76 Fed. 34, 36; Minshull $v$. Oakes (I858, Exch.) 2 Hurl. \& Norm. 793; Dyson v. Forster [I909, H. L.] A. C. 98; Prout v. Robey (I872, U. S.) I5 Wall. 47I; Purvis v. Shuman (I9I6) 273 Ill. 286, II2 N. E. 679; Morse v. Aldrich (1837, Mass.) I9 Pick. 449. Citations might be added almost indefinitely.

${ }^{10}$ Barnard v. Godscall (I612, K. B.) Cro. Jac. 309; Mason v. Smith (I88I) I3I Mass. 5I0, 5 II (semble); Jones v. Parker (1895) I63 Mtass. 564, 568, 40 N. E. I044, I045; Neal v. Jefferson (I912) 212 Mass. 517, 522, 99 N. E. 334, 335; Auriol v. Mills (I790, K. B.) 4 T. R. 94, 99.

${ }^{*}$ The leading case is Tulk v. Moxhay (1848, Ch.) 2 Phil. 774. The discussion of this principle is beyond the scope of this article.

${ }^{2}$ Albiani v. Evening Traveller Co. (IgI4) 220 Mass. 20, 107 N. E. 406, and cases cited. Conveyances in fraud of creditors are another familiar example of the same principle.
} 
against persons who take with notice, which rests upon privity of conscience.

We pass. therefore, to our main problem, namely, what principle governs the running of covenants in leases by reason of privity of estate. This problem, as we shall see, divides into two parts-the question as to what coyenants the policy of the law will permit to run, and the question as to what covenants the parties to the instrument intend shall run. As was said in Masury v. Southworth: ${ }^{22}$

"From this view, it is obvious that, as to the first point, the nature and character of a covenant which may inhere in the land, we are to look at the reason and policy of the law; and, as to the second point, whether it does so inhere as to give a right and create an obligation in the case of assignees, we must look at the intent of the parties creating the estate. The law must say that the covenant may inhere, and the parties must say that it shall inhere."

II

THE TEST FOR COVENANTS WHICH THE LAW PERMITS TO RUN

Taken alone St. 32 Hen. VIII, c. 34, might perhaps be construed broadly enough to apply to almost any covenant which caprice might insert in a lease. It was, however, passed to correct an injustice-the loss by those in privity of estate of the contractual relation which rendered that estate of mutual value. Moreover, the statute was in clear derogation of the then common law. It was, therefore, strictly construed. In spite of the broad language employed, the court resolved 'in Spencer's Case $e^{23}$ that as a matter of law a covenant in a lease could not run "if the thing to be done be merely collateral to the land and doth not touch or concern the thing demised in any sort." In so construing the statute the court confined it strictly to the mischief which it was enacted to correct.

If performance of the covenant does not "touch or concern" the thing demised in any sort" privity of estate in the thing demised furnishes no reason for imposing a mutuality of obligation and of remedy where none previously existed. So far as collateral covenants are concerned, the continuance of the mutual relation to the property does not require a remedy to the covenantee against the successors or assigns of the covenantor. The assign of the covenantee may also be left to such remedy as he may be able to enforce against the covenantor in the name of the covenantee, upon the theory of an actual assignment of the covenant. If once it be determined that performance of the covenant does not "touch or concern the thing demised in any sort," it is plain that

2 (I859) 9 Ohio St. 340, 348.

${ }^{23}$ (1583, K. B.) 5 Co. Rep. r6a. 
neither success nor failure in enforcing it affects the mutual relation of the assigns to the thing demised. In such a case the mischief which the statute was intended to correct.does not exist and the statute may well be restrained by construction so as not to apply.

On the other hand, Spencer's Case recognizes that "if the thing to be done" does "touch or concern the thing demised" the covenant is one which the law permits to run and to bind assigns. This conclusion is somewhat confused by the seeming conflict between the first and the second resolution and by the further discussion as to the necessity of "express words" to bind assigns in certain cases. ${ }^{24}$ But if Spencer's Case leaves the matter in any doubt, the point has been established by numerous subsequent decisions. ${ }^{25}$ The question, then, becomes what is meant by the requirement that "the thing to be done" must "touch or concern the thing demised."

Congleton v. Pattison ${ }^{26}$ was an action at law by the lessor, the Parish of Congleton, against the assign of the lessee upon a covenant whereby the lessee bound himself and his assigns not to employ workers from other parishes upon the demised premises. The defendant demurred. In sustaining the demurrer Lord Ellenborough said:

"This is a covenant in which the assignee is specifically named; and though it were for a thing not in esse at the time, yet being specifically named, it would bind him if it affected the nature, quality or value of the thing demised, independently of collateral circumstances; or if it affected the mode of enjoying $i t^{3 \prime 27}$ (italics ours).

The learned judge then showed that neither the nature, quality nor value of the land demised, nor the mode of enjoyment thereof (i. e., the purpose for which it was or might be used) was in any way affected by the residence of the workers employed, and then concluded:

"The covenant, therefore, not directly affecting the nature, quality, or value of the thing demised, nor the mode of occupying it, is a collateral covenant, which will not bind the assignee of the term, though named; . . . ."

Vernon v. Smith ${ }^{28}$ was an action of covenant by the assign of the lessor against the lessee upon a covenant by the lessee and his assigns with the lessor and his assigns to insure the buildings then or thereafter erected upon the demised premises against fire, in the joint names of the defendant and of the lessor and his assigns. The statute of (I774) I4

${ }^{24}$ See notes I and 2 supra.

${ }^{25}$ I5 C. J. 1240, note 5I, where many authorities are collated.

${ }^{25}$ (1808, K. B.) Io East, r30, I35. See also Bigelow, The Content of Covenants in Leases (I9I4) I2 MICH. L. Rev. 639, reprinted in (I9I4) 30 L. QUART. REV. 3 I9.

${ }^{27}$ See also Hunt v. Danforth (I856, C. C. D. R. I.) 2 Curt. 592; Mesa Market Co. v. Crosby (I909, C. C. A. 8th) I74 Fed. 96, I02.

${ }^{23}$ (I82r) 5 Barn. \& Ald. I. 
Geo. 3 , c. 78 , provided that in case of fire the proceeds of the policy should be laid out in rebuilding the burned structures. The defendant demurred. The court (Abbot, C.J., Bayley, Holroyd, and Best, J.J.) unanimously overruled the demurrer. ${ }^{29}$ In the course of his opinion Best, J., laid down the following test for the covenants which the law permits to run $:^{30}$

"It is a covenant beneficial to the owner of the estate, and to no one but the owner of the estate; and therefore may be said to be beneficial to the estate, and so directly within the principle on which covenants are made to run with the land."

To illustrate the test further, he put the case of a covenant to renew the lease, which is universally held to run, ${ }^{31}$ and said:

"The covenant here mentioned is not beneficial to the estate granted, in the strict sense of the words, because it has no effect until that estate is at an end, but it is beneficial to the owner as owner, and to no other person. By the terms, collateral covenants, which do not pass to the assignee, are meant such as are beneficial to the lessor, without regard to his continuing owner of the estate. This principle will reconcile all the cases."

Vyzyan v. Arthur ${ }^{32}$ was an action of covenant by the devisee of the lessor against the administratrix of the lessee upon a covenant by the lessee to yield certain rent and further to do suit to the mill of said lessor, his heirs and assigns, by grinding at said mill all corn which should be grown upon the demised premises during the term. The defendant demurred. The court (Bayley, Holroyd, and Best, J.J.) overruled the demurrer holding that the covenant in question was in the nature of a rent service. ${ }^{33}$ Best, J., again states the test as follows: $:^{34}$

"The general principle is, that if the performance of the covenant be beneficial to the reversioner, in respect of the lessor's demand, and to no other person, his assignee may sue upon it; but if it be beneficial to

${ }^{20}$ Masury v. Southworth (I859) 9 Ohio St. 340; Thomas v. Vonkapff (1834, Md.) 6 G. \& J. 372; Northern Trust Co. v. Snyder (I896, C. C. A. 7 th) 76 Fed. 34, accord.

${ }^{30}$ Vernon v. Smith, supra.

"See Abbot, Leases and the Rule against Perpetuities (19I8) 27 YALE LAW JourNAL, 878, 883-884, notes 17 to $2 x$, and cases cited. Leominster Gas Light Co. v. Hillery (Ig08) I97 Mass. 267, 83 N. E. 87a; Lamson v. Coulson (1920) 234 Mass. 288, 295, 125 N. E. 55I, 554; Warner v. Cochrane (1904, C. C. A. 2d) I28 Fed. 553.

${ }^{32}$ (I823, K. B.) I Barn. \& Cress. 4ro.

${ }_{3}$ This mode of construing the covenant as a rent service must be sparingly applied, otherwise almost any covenant which the landlord chooses to insert may be held to run as an additional rent, thereby abolishing the distinction between covenants which do touch and concern the land and those which do not. Cf. Gower v. Postmaster-General (I887, Ch.) 57 L. T. (N. S.). 527.

${ }^{34}$ Vyoyan v. Arthur, supra, at p. $4 \mathrm{I} 7$. 
the lessor, without regard to his continuing owner of the estate, it is a mere collateral covenant, upon which the assignee cannot sue."35

The test suggested in Vernon v. Smith and in Vyvyan v. Arthur is the complement of the test suggested in Congleton v. Pattison. Both tests turn upon the effect of performance. Congleton v. Pattison defines what effect performance of the covenant must have upon the property demised. Vernon v. Smith and Vyvyan v. Arthur define how performance must affect the covenantee. Yet if a covenant answer to the one test it will generally answer to the other. Usually performance of the covenant will not directly affect the nature, quality or value of the thing demised, or the mode of occupying it or enjoying it without also affecting the owner, as owner, that is, affecting him through or by reason of his ownership of the property. Similarly if performance of the covenant affects the owner through or by reason of his ownership, such performance will usually affect the property itself in one of the modes.pointed out in Congleton v. Pattison. Yet the two tests are so different in form that each offers an excellent method of checking cases which are upon the border line of the other. If a covenant successfully passes both tests, it seems reasonably safe to assume that it does "touch or concern the thing demised."

No better illustrations could be found than Congleton v. Pattison and Vyzyan v. Arthur. It might be thought, perhaps, that a covenant which . prescribed what persons could be employed upon the demised land, affected the mode of occupying or enjoying it. Yet such a covenant is in no sense beneficial to the lessor as owner. It might, indeed, be beneficial to the parish, as a parish, to require that only those who dwelt in the parish could be employed upon the land demised. But such a benefit was a benefit to the parish only in its capacity as a municipal corporation, and was of no value to it in its capacity as landlord. Hence the test of Vernon $v$. Smith demonstrates the soundness of the result reached in Congleton v. Pattison.

On the other hand, the test employed in Congleton v. Pattison throws considerable doubt upon the actual decision in Vyvyan v. Arthur. Undoubtedly, it was of personal benefit to the lessor that the corn grown upon the demised premises should be ground at his mill. But his ownership of the mill was, so far as appears, entirely independent of his ownership of the demised premises. It is difficult to perceive how performance of this covenant affected the demised land in any of the modes described in Congleton v. Pattison, unless we adopt the view of the court that 'such performance was in the nature of an additional rent.

\footnotetext{
${ }^{35}$ This test was quoted or approved in the following cases: Allen $v$. Culver ( 1846, N. Y.) 3 Denio, 284; Laffan v. Naglee (1858) 9 Calif. 662; Dyson $v$. Forster [rgog, H. L.] A. C. 98, 102.
} 
But if the landlord has sold the mill, he would clearly receive no benefit as landlord by insisting that the corn in question be ground at a mill which had passed into the hands of a stranger. Thus while the result in Vyvyan v. Arthur seems doubtful, and indeed, has been doubted, ${ }^{38}$ the validity of the test laid down by Justice Best in that case, and in Vernon v. Smith, remains unshaken. The doubt'as to the result in Vyryan v. Arthur simply illustrates the wisdom of proving the result reached under that test by applying also the complementary test of Congleton ข. Pattison.

In one respect the language of the Vernon $v$. Smith and $V y$ yyan $v$. Arthur test seems to require qualification. Literally applied, the language of that test would seem to make the running of the covenant depend on whether performance of the covenant was beneficial to the lessor as owner of the reversion. This is not unnatural since in both Vernon v. Smith and Vyvyan v. Arthur the plaintiff was either the lessor or an assign of the lessor. But the lessee is likewise owner of an interest in the land demised, namely, the leasehold. A covenant may run, if performance of it be beneficial to the lessee as owner of the leasehold, even though it be burdensome to the lessor as owner of the reversion. For example, an option to the lessee to renew the lease ${ }^{37}$ or to purchase the reversion ${ }^{38}$ may run. Both options are in operation burdensome to the lessor as owner of the reversion, since the lessee will not exercise them unless they are more favorable to him than any independent agreement which he can negotiate with the owner of the reversion. So, also, a covenant by the lessor to purchase at the expiration of the term such improvements as the lessee may have annexed to the soil may run, ${ }^{39}$ although such a covenant is clearly burdensome to the owner

\footnotetext{
${ }^{\Im}$ See Gower $v$. Postmaster-General, supra note 33 , where it was held that an agreement to pay taxes upon other land not included in the demise was not an additional rent service and did not run.

${ }^{37}$ See note 28 . Indeed, this is recognized in Vernon v. Smith (I82x, K. B.) 5 Barn. \& Ald. I.

${ }^{33}$ Prout v. Robey (1872, U. S.) I5 Wall. 47I; Ankeny v. Richardson (I9II, C. C. A. 8th) I87 Fed. 550; Hollander v. Central Metal Co. (I908) Iog Md. I3I, 7I Atl. 442; Laffan v. Naglee (I858) 9 Calif. 662; Blakeman v. Miller (IgoS) I36 Calif. I38, 68 Pac. 587; Hagar v. Buck (1872) 44 Vt. 285; Sizer v. Clark (1903) I16 Wis. 534, 93 N. W. 539; Peters v. Stone (1906) 193 Mass. 179; 186, 79 N. E. 336,337 (semble). Contra, Woodall v. Clifton [1905] 2 Ch. 257; Worthing Corp. v. Heather [1906] 2 Ch. 532. In both the latter cases the option could be exercised at a period too remote under the letter of the rule against perpetuities. Perhaps the result might be supported on this ground, although the author is of opinion that the rule against perpetuities is inapplicable to such an option inserted in a lease, if the option must be exercised during the term. See Abbot, op. cit., 27 Yale LAw Journal, 878, 885; Eastman Marble Co. v. Vermont Marble Co. (I920) 236 Mass. 138, I56, I28 N. E. I77 (semble); Battelle v. Worcester (I920) 236 Mass. 395, I28 N. E. 63I and note 4I infra.

${ }^{2}$ Mansel v. Norton (1883, C. A.) L. R. 22 Ch. Div. 769; Hunt v. Danforth
} 
of the reversion, in that it compels him to purchase what would otherwise come to him without cost. Thus, while the principle of Vernon $v$. Smith and Vyzyan v. Arthur is clearly sound, the test itself should be more broadly phrased so as to include a covenant which is beneficial to the lessee as owner of the leasehold, even though that covenant be burdensome to the lessor as owner of the reversion. If any covenant which touches and concerns the land may be enforced as between assigns by reason of privity of estate, it is plainly immaterial whether the benefit of performance would have accrued, had there been no assignment, to the lessor as owner of the reversion or to the lessee as owner of the leasehold.

It must be noted, however, that the running of covenants, like the creation of covenants, will not be permitted to infringe upon positive rules of law or considerations of public policy. Thus, even though the covenant touches and concerns the land, it will not run if enforcement would violate the rule against perpetuities. An option to purchase the demised land manifestly touches and concerns the land itself, and so falls within the strictest limits of the tests which ordinarily govern the running of covenants. ${ }^{40}$ There is conflict as to whether such as option, if exercisable during the term, will run when inserted in a lease for over twenty-one years.11 It seems, however, to be clearly settled that if such an option, exercisable at a period too remote, be inserted in a deed, ${ }^{42}$ it will not run. There is conflict as to whether such a covenant

(I856, C. C. D. R. I.) 2 Curt. 592; Purvis v. Shumnan (I9I6) 273 Ill. 286, II2 N. E. 679; Frederick v. Callahan (1875) 40 Iowa, 3II; Stockett v. Howard (I870) $34 \mathrm{Md}$. I2I; Hollywood v. First Parish (1906) I92 Mass. 269, 78 N. E. 124; Conover v. Smith (1864) I7 N. J. Eq. 5I; Lametti v. Anderson (1826, N. Y.) 6 Cow. 302; Douglaston Realty Co. v. Hess (Ig08) 24 App. Div. 508, IoS N. Y. Supp. I036; Napier v. Darlington (I87I) 70 Pa. 64; Ecke v. Fetzer (I886) 65 Wis. 55,26 N. W. 266 . Contra, Bream v. Dickerson (1840, Tenn.) 2 Humph. 126. The following cases do not conflict, but rest upon the ground that the intention that the covenant should run was held not to have been sufficiently expressed. Grey v. Cuthbertson (1785) 2 Chit. 482 (overruled? Mansell $v$. Norton, supra); Minshill v. Oakes (I858, Exch.) 2 Hurl. \& Norm. 793; In re Robert Stephenson [1915] I Ch. 802; see also Ecke v. Fetzer, supra); Hansen v. Meyer (1876) 8I IIl. 32I (overruled? Purvis v. Shuman, supra); Thompson v. Rose (I828, N. Y.) 8 Cow. 266; Coffin v. Tallman (I854) 8 N. Y. 465.

${ }^{-10}$ See cases cited note 38 supra.

"It was specifically enforced in Prout v. Robey, supra noto 38; Hollander $v$. Central Metal Co., supra note 38 ; Hagar v. Buck, supra note 38 ; see also Eastman Marble Co. v. Vermont Marble Co., supra note 38 , at p. 156 (semble); Battelle v. Worcester, supra note 38 ; Abbot, op. cit., 27 YAlE LAw JouRnal, 878. In England specific performance is denied. Woodall v. Clifton, supra note 38 ; Worthing Corp. v. Heather, supra note 38; Gray, Perpetuities (3d ed. Igr5) sec. $230 \mathrm{~b}$.

${ }^{2}$ London \& $S . W$. Ry. v. Gomm. (I881) L. R. 20 Ch. Div. 562; Trevelyan v. Trevelyait ( 1885 , Ch.) 53 L. T. (N. s.) 853 ; H. J. Lewis Oyster Co. v. West 
is good as against the original covenantor or his estate. ${ }^{43}$ Consideration of the rule against perpetuities is beyond the scope of this article.44 But the cases noted show that in determining what covenants the law will permit to run we must consider not only what covenants touch and concern the land, but also whether the running of the covenant, if permitted, will conflict with positive rules of law or considerations of public policy.

It may be suggested, however, that a distinction may be taken between leases and deeds. A lease defines the mutual relations of landlord and tenant. No considerations of public policy require that courts should be jealous of the running of covenants in leases, since any obligations or restrictions thereby imposed cannot in the ordinary case outlast the term. Different considerations apply in the case of a deed. If a covenant in a deed be held to run, it may restrict or burden the land conveyed for an indefinite period, thereby interfering with its free use and possibly imposing a very real restraint on alienation. Similar considerations may also apply to covenants in long leases which restrict or burden other land for the benefit of the land demised, since such covenants may measurably have the same effect as covenants inserted in deeds. But where the covenant in a lease applies only to the land demised, and must cease to affect it when the term expires, the courts may properly take a liberal view as to what covenants the law will permit to run.

\section{III}

COVENANTS RELATING TO OTHER IAND AND TO THINGS NOT IN BEING

It is not the purpose of this article to give an exhaustive list of covenants which the law permits to run. That is the function of a

(1919) 93 Conn. 5I8, I07 Atl. r38; Wintsor v. Mills (I892) I57 Mass. 362, 32 N. E. 352; Hardy v. Galloway (I892) rII N. C. 5I9, I5 S. E. 890; Barton v. Thaw (I914) $246 \mathrm{~Pa}$. 348, 92 Atl. 3I2; Starcher v. Duty (1907) 6I W. Va. 373, 56 S. E. 524; Woodall v. Bruen (1915) 76 W. Va. 193, 85 S. E. x7o. The case of Mineral Land \& Imp. Co. $v$ Bishop Mining Co. (IgI6) I34 Minn. 4I2, I59 N. W. 966 seems to rest upon statute.

${ }^{2}$ In Eastman Marble Co. v. Vermont Marble Co. (1920) 236 Mass. I38, I28 N. E. I77, such an option, inserted in a deed, was held to be void as a restraint on alienation, but the case of a lease was expressly distinguished at p. 156. In Worthing Corp. v. Heather [Ig06] 2 Ch. 532, an option to purchase the reversion inserted in a lease for thirty years was held to be unenforceable in equity against an assign of the lessor, but damages were awarded against the estate of the covenantor. The two cases may perhaps be distinguished upon the ground that, in the first case, the option was inserted in a deed, and, in the second case, it was inserted in a lease. See supra note 38 and Abbot, op. cit., 27 YALE LAW JoURNAL, 878 .

"See Abbot, op. cit., 27 Yale LaW JoURNal, 878. 
digest or text book. It may not be without worth, however, to consider, for purposes of illustration, two classes of covenants which have caused some difficulty and confusion, namely, covenants relating to land other than that demised, and covenants relating to things not in being.

It is plain that even under the rule in Spencer's Case the subject matter of the covenant need not be the land demised. It is enough if the covenant touches and concerns the thing demised. Congleton $v$. Pattison, Vernon v. Smith, and Vyvyan v. Arthur make it clear that the true criterion is whether performance of the covenant affects the land. The first question, therefore, is whether a covenant to do something in relation to other land, or upon it, may so touch and concern the land demised that such a covenant may run.

In Sampson v. Easterby ${ }^{45}$ one $T$, being the owner of certain mines, demised the same to defendant. The lease recited an agreement between the defendant and the owner of the mines to pull down and replace a certain smelter, which was used in connection 'with the mines, and which stood upon land not included in the demise. The lease contained a covenant by the lessee and his assigns, with the lessor and his assigns, to keep the new smelter in repair and so to leave it at the expiration of the term. The devisee of the assign of the lessor sued the lessee upon the latter covenant and the defendant demurred. The court overruled the demurrer, holding (I) that a covenant to build the new smelter should be implied, and (2) that even though the new smelter was to be placed upon land not included in the demise, it was so connected with the value and enjoyment of the mines that the covenant to build it and leave it in good repair could and did run.

In Ricketts v. Enfield Church Wardens, ${ }^{4 B}$ the church wardens leased certain land to $B$, with a covenant by them and their assigns with $B$ and his assigns not to build beyond a certain line upon the adjoining premises. B assigned to plaintiff, who sues upon the covenant. Held, that even though the covenant relates to the adjoining land it is for the benefit of, and so runs with, the land demised, and plaintiff may sue thereon.

In Lyle v. Smith, ${ }^{47}$ the lessee of certain property covenanted for himself and his assigns, with the lessor and his assigns, to contribute to the repair of a sea wall, erected for the protection of the leased premises and other premises, but not upon the premises demised, in the proportion

(I829, K. B.) 9 Barn. \& Cress. 505 affirmed sub nom. Easterby v. Sampson (I830, Exch. Ch.) 6 Bing. 644. Approved Dewar v. Goodman [I909, H. L.] A. C. 72,77 .

46 [I909] I Ch. 544. See also Thruston v. Minke (I870) 32 Md. 487; Clark v. Martin (I865) $49 \mathrm{~Pa} .289$.

${ }^{17}$ [1909, K. B.] 2 Ir. Rep. 58. See also Morland v. Cook (I868) L. 'R. 6 Eq. Cas. 252, where a similar result was reached as to a similar covenant contained in a deed of partition. 
that the leased frontage bore to the total frontage. The action was brought to compel the assign of the lessee to contribute his proportion of the cost of such repairs. Held, that as the wall was for the benefit, support and maintenance of the thing demised, the covenant ran with the land demised and could be enforced against defendant.

Lack of space forbids setting out further cases to establish the proposition that a covenant touching land other than that demised may run. ${ }^{48}$ It is enough to point out that each of the covenants above considered, two of which are affirmative and one negative, successfully passes the tests laid down in Congleton v. Pattison, Vernon v. Smith, and Vyvyan $v$ Arthur. We pass on to consider several cases where the covenant touching other land was held to be collateral.

In Thomas $v$. Hayward, ${ }^{49}$ the lessee covenanted for himself and his assigns to use the demised house for the sale of beer and spirits, and the lessor covenanted for himself and his assigns that, during the term, he would not build or keep or be interested in building or keeping any house for the sale of beer or spirits within half a mile of the demised premises. An assign of the lessee sued the lessor upon the latter covenant and the defendant demurred. Held, that the covenant in question concerned the business to be carried on upon the demised premises, rather than the land, and could not run.

In Gower v. Postmaster-General, ${ }^{50} \mathrm{~A}$, by an underlease, demised to B all the premises comprised in two head leases except certain premises previously demised to $\mathrm{X}$ by a prior underlease. B covenanted for himself and his assigns to pay all taxes which might be assessed, not only on the premises demised to him, but also on the premises previously

${ }^{43}$ A considerable number of cases are collected in I2 C. J. I240, note 52. See also Morse v. Aldrich (1837, Mass.) I9 Pick. 449; Norman v. Wells (1837, N. Y.) I7 Wend. I36; Shaber v. St. Paul W. Co. (1883) 30 Minn. 179.

(I869) L. R. 4 Exch. 3II. The case is significant as showing that the intention of the parties that the covenant shall run will not prevail if the covenant be of the kind which the law will not permit to run. Congleton v. Pattison (I808, K. B.) Io East, I30 is another example. In view of the lessee's covenant the case seems to take a rather narrow ground. Cf. Clegg v. Hands (ISga, C. A.) L. R. 44 Ch. Div. 503, which held that in a lease of a public house a convenant by the lessee and his assigns with the lessor and his assigns not to buy or sell any beer other than that bought of the lessor will run and may be enforced in equity by the assign of the lessor. In Norman v. Wells supra, A. demised a saw mill and covenanted not to establish another saw mill on the same mill stream. Held, that the covenant runs.

${ }^{80}$ (I887, Ch.) 57 L. T. (N. S.) 527. The plaintiff contended that the covenant to pay taxes upon the land, not demised to $B$, might be deemed an additional rent as in Vyzyan v. Arthur. The lease did not so provide and the contention was rejected. Query, as to how far covenants which would ordinarily be collateral might be made to run by providing that the rent should be a sum of money and performance of the act in question. Cf. Barnard v. Godscall (I6r2, K. B.) Cro. Jac. 309. 
demised to X. B assigned to the defendant. Held, that the covenant to pay taxes on the premises demised to $X$ was collateral and did not run so as to bind the defendant.

In Dewar v. Goodman, ${ }^{51} \mathrm{~A}$, in 1820 , made a head lease of a large tract of land to $B$, who covenanted for himself and assigns to repair all the buildings which might be erected on the premises during the term, with a provision for reentry by lessor in case of breach. Two hundred and eleven houses were so built. The head lease became vested in $C$, who demised two of the houses to $D$, and covenanted for himself and assigns with $\mathrm{D}$ and assigns to perform all the covenants of the head lease as to all the premises not included in the under lease. $C$ assigned to Goodman (defendant) and D assigned to Dewar (plaintiff). Both Goodman and $D$ permitted the two hundred and nine houses not included in the sublease to get out of repair, and A's assign, the head landlord, entered and terminated both head lease and sublease. Dewar sues Goodman upon the covenant to repair the two hundred and nine houses . not included in the sublease, alleging that Goodman's breach of that covenant destroyed the sublease. The House of Lords, affirming the judgment below, held that the covenant to repair the two hundred and nine houses not included in the sublease was not a special covenant with the sublessee for quiet enjoyment, did not touch and concern the land demised to him by the sublease and, therefore, could not run. In other words, a covenant, the performance of which directly touches and concerns the sublease, may be collateral with respect to the land thereby demised. It may be observed that while the covenant in Dewar v. Goodman might pass the Vernon v. Smith test, it does not directly affect "the nature, quality or value of the thing demised nor the mode of occupying it" if that test be literally and narrowly applied, and so fails to pass the test laid down by Congleton v. Pattison. Putting aside the fact that the sublessee may lose his lease if the covenant be not performed, which might properly be taken care of by a covenant for quiet enjoyment, he derives no benefit from the repair of houses which do not stand on the demised premises. The case shows the value of the double test and is a striking example of the unwillingness of the English courts to extend the rule as to convenants running with the land. The court, however, recognizes that a covenant touching or to be performed upon land other than that demised is not as matter of law collateral in all cases, for Lord Collins says, at p. 77:

"I think counsel for defendant perhaps relied too much on the contention that privity of estate was not established between the plaintiff and defendant in the action in respect of the land on which the covenant of the sub-lessee was to be performed. No doubt privity of estate must exist between the assignee of the reversion and the assignee of the

${ }^{31}$ [1909, H. L.] A. C. 72, affirming [1908, C. A.] I K. B. 94. 
land demised, but privity of estate between the same parties is not vital in respect of the land on which the covenant is to be performed. The reason why the covenant to do something on land other than that demised presumably does not run is not because there is no privity of estate in the land on which the covenant is to be performed, but because such a covenant is prima facie collateral, i. e., does not touch or concern the land demised. But instances may be imagined of covenants to do things on land other than that demised which touch and concern so nearly the land demised as to run with it. Of this Sampson v. Easterby is an instance, if it be assumed, as it seems to have been, that no demise was to be implied of the site on the waste where the mill was to be built. . . I I agree with the Court of Appeal that Sampson v. Easterby is no authority for the running of the covenant in this case. It does decide that a covenant may run although there is no privity of estate in the land on which the covenant is to be performed, but it in no way supports the contention that the covenants in this case were other than collateral."

We turn to covenants, the subject matter of which is not in being. The distinction between covenants whose subject matter is in being and covenants whose subject matter is not in being is made by Spencer's Case. While the first resolution, if literally construed, might seem to indicate that a covenant whose subject matter is not in being-e. g., a covenant to build a new structure upon the demised premises-cannot run, the second resolution shows that this is not the case. It is settled that a covenant may run even though the subject matter of it is not in being. Thus, a covenant by the lessee to construct improvements and to surrender the same in good repair, ${ }^{52}$ or a covenant to repair, ${ }^{53}$ or to insure $^{54}$ improvements which may in the future be placed upon the land, may run. The same is true of a covenant to supply the demised premises with water ${ }^{55}$ and of certain covenants by the lessee touching a railway to be built by him on the land demised. ${ }^{58}$ So, also, a covenant by the lessor to purchase such improvements as may thereafter be placed by the lessee upon the demised premises may run with the land. ${ }^{57}$ In

${ }^{62}$ Sampson v. Easterly (ז829, K. B.) 9 Barn. \& Cress. 505, affirmed (Exch. Ch.) sub non. Exsterby v. Sampson (1830) 6 Bing. 644; Peters v. Stone (1906) 193 Mass. I79, 79 N. E. 336; see also Allen v. Culver (I846, N. Y.) 3 Denio, 284 ; Hayes v. Nère York M. Co. (1874) 2 Colo. 273; Magoon v. Eastman (1912) 86 Vt. 261, 84 At1. 869; Dewar v. Goodman, supra note 51.

${ }^{*}$ Allen v. Culver, supra note 52; Coburn v. Goodall (1887) 72 Calif. 498; Magoon $v$. Eastman, supra note 52; Minshull v. Oakes (1858, Exch.) 2 Hurl. \& Norm. 793. But not buildings upon other land. Dewar v. Goodman, supra note 52 .

*Vernon v. Smith (I82I, K. B.) 5 Barn. \&. Ald. I; Masury v. Southworth (I859) 9 Ohio St. 340; Northern Trust Co. v. Suyder (I896, C. C. A. 7 th) 76 Fed. 34; see also Thomas v. Vonkapff (I834, Md.) 6 G. \&. J. 372.

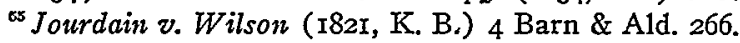

${ }^{s s}$ Hemingway v. Fernandes (1842, Ch.) I3 Sim. 228.

${ }^{87}$ See supra note 39 . 
all these cases the covenants may run although the subject matter of the covenant is not the land and is not in being when the covenant is made.

Performance of each of these covenants intimately affects the land. Every one of them passes both the test laid down by Congleton v. Pattison and also the test laid down by Vernon $v$. Smith and $V y$ yyan $v$. Arthur. Indeed, the subject matter of the çovenant in both the latter cases was neither the land itself nor a thing in being at the time the covenant was made. In Vernon $v$. Smith the covenant was to insure buildings which might in future be placed upon the land, while in Vyvyan v. Arthur the subject matter of the covenant was corn which might be grown thereafter upon the demised premises. It is evident therefore, that in determining whether the covenant is of such a character that the law will permit it to run with the land, the question whether the subject matter of the covenant is, or is not, in being is not decisive. The controlling fact is the effect of performance. If that passes the tests laid down by Congleton v. Pattison and Vernon v. Smith it may ordinarily be assumed that the covenant is one which the law permits to run, even though the subject matter of it be other land or a thing not yet in being.

\section{IV}

THE INTENTION OF THE PARTIES THAT THE COVENANT

SHALL RUN

If the covenant be one which the law permits to run, the question whether it shall run is one of intention. Although an express provision that the covenant shall run will not avail if the covenant be collateral, the law does not require that any covenant shall run against the will of the parties to the lease. As the question whether a covenant which in law may run, shall run, is purely one of intention, we should expect that that intention would be collected from the entire instrument construed in the light of the circumstances under which it was made. Such seems to be the law in a few advanced jurisdictions. ${ }^{59}$ But much confusion as to this question of intention has been caused by the distinction taken in the first and second resolutions in Spencer's Case.

The first resolution declares that "where the covenant extends to a thing in esse, parcel of the demise . . . . [it] shall bind the assignee although he be not bound by express words." The second resolution

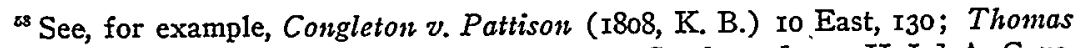
v. Hayward (I869) L. R. 4 Exch. 3II; Dewar v. Goodman [I909, H. L.] A. C. 72.

${ }^{*}$ Purvis v. Shuman (I916) 273 I11. 286, 294, II2 N. E. 679; Sexauer v. Wilson (1907) 136 Iowa, 357, 362, 113 N. W. 94I; Peters v. Stone (1906) I93 Mass. I79, 185, 79 N. E. 336,337 ; Hollyzwood v. First Parish (I906) I92 Mass. 269, 78 N. E. 124; Masury v. Southworth (I859) 9 Ohio St. 340, 359. 
declares that a covenant to "make a new wall upon some part of the thing demised ... shall bind the assignee by express words." These two resolutions distinguish covenants which may run into two groups, namely, covenants as to a thing in being and covenants to make new things in the future. According to Spencer's Case, "express words" are not required to bind assigns to perform covenants of the first class, while "express words" are required to bind assigns to perform covenants of the second class. Thus, the effect of these two resolutions seems to be that, if the covenant relates to a thing in being, the intention that it shall run is presumed to exist unless rebutted, while, if the covenant relates to a thing not in being, the intention that it shall not run is presumed unless the intention that it shall run is declared by "express words." So considered, these two resolutions seem to lay down two rules of construction which assume, in the absence of "express words," that the intention that the covenant shall or shall not run depends upon whether the subject matter of the covenant is or is not in being.

In the last analysis, intention is a question of fact. A rule of construction establishes a presumption as to that fact. But a presumption may easily be misused to defeat intention rather than as a means of determining intention. If the presumption be flung into the scale in the first instance, and then the instrument be examined to ascertain whether the language thereof is sufficiently clear to rebut the presumption, there is much danger that an a priori conception of the court may be substituted for the actual intention of the parties to the instrument. If, on the other hand, the instrument be first examined in the light of all the circumstances and the presumption be resorted to only when the scales hang even, it performs a legitimate function in substituting a definite make-weight to determine what would otherwise be a mere guess.

The question whether a covenant which may run is intended to run is simply the question whether the covenant is intended to enure to and bind all the persons who may from time to time occupy respectively the position of landlord and of tenant of the demised premises, or whether it is intended to be personal to the original parties to the lease. The fact that it is inserted in the lease is a circumstance which in and of itself would seem to indicate that it was intended to govern all who might occupy the mutual relation of landlord and tenant. The first resolution recognizes and gives effect to this natural assumption as to intention in all cases where the subject matter of the covenant is in existence when the lease was made. Broadly speaking, it seems to be the accepted rule in most jurisdictions. The second resolution apparently assumes that a covenant which may run is nevertheless intended to be personal if it relates to a thing not in being, unless the parties declare a contrary intention by express words. There seems to be no logical basis for this 
assumption, and it has been severely criticized. ${ }^{60}$ But it must be admitted that the authority of the second resolution in Spencer's Case has not spent its force in many jurisdictions, ${ }^{61}$ although the tendency seems to be to restrict it to its precise facts, viz., an absolute covenant to make a new thing, and to escape from it where possible. ${ }^{62}$

The tendency to restrict the second resolution so far as may be appears in a variety of forms. Some courts have been very astute to discover that the covenant related in some aspect to a thing in being, and so fell within the first resolution. ${ }^{63}$ In England, the case of Grey v. Cuthbert$\operatorname{son}^{64}$ held that a covenant to buy such bushes as might be on the land at the expiration of the lease would not run where assigns were not named, but this case seems to be much shaken, if not overruled, by Minshull $v$. Oakes, ${ }^{65}$ which held that a covenant to repair such buildings as were or might be placed on the land would run even though assigns were not expressly bound. The latter case confined the second resolution in Spencer's Case to an absolute covenant to make a new thing, and distinguished it from a covenant which was contingent upon the existence of the future buildings to which it related. Minshull v. Oakes has been followed in many American jurisdictions ${ }^{66}$ but there is a case to the contrary in Tennessee. ${ }^{67}$ In Illinois, Hansen v. Meyer ${ }^{68}$ followed Grey v. Cuthbertson but seems to be shaken, if not overruled, by Purvis v. Shuman. ${ }^{99}$ When these cases are considered with those which frankly criticize the rule of construction laid down by the second resolution as illogical ${ }^{70}$ and with those which adopt what appears to be the sounder

${ }^{60}$ Masury v. Southworth, supra note 59; Sexauer v. Wilson, supra noto 59 ; Purvis v. Shuman, supra note 59; Mintshull v. Oakes (1858, Exch.) 2 Hurl. \& Norm. 793; Bald Eagle Ry. v. Nittany, etc. Ry. (r895) I7I Pa. 284, 294, 33 Atl. 239.

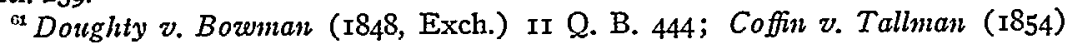
8 N. Y. 465 .

"Minshull v. Oakes (1858, Exch.) 2 Fur1. \& Norm. 793; In re Robert Stephenson [1915] x Ch. 802; Purvis v. Shuman, supra note 59; Sexanter v. Wilson, supra note 59; Peters v. Stone, supra note 59; Conover v. Snith (I864) I7 N. J. Eq. 5I; Masury v. Southworth, supra note 59; Napier v. Darlington (187I) 70 Pa. 64; Ecke v. Fetzer (1886) 65 Wis. 55, 26 N. W. 266; Northern T. Co. v. Snyder (1896, C. C. A. 7 th) 76 Fed. 34; Tuttle v. Leiter (I897, C. C. N. D. III.) 82 Fed. 947.

"See, for example, Woodruff v. Trenton Water P. Co. (I856) ro N. J. Eq. 489, 505; Winfield v. Heming (1870) 21 N. J. Eq. 188, 189; Allen v. Culver ( 1846, N. Y.) 3 Denio, 284. .

4 (1785) 2 Chit. 482 .

"see note 62 supra.

${ }^{6}$ See notes 57 and 39 supra.

${ }^{\circ}$ Bream v. Dickerson (1840, Tenn.) 2 Humph. I26.

${ }^{65}$ (1876) 8I IIl. 32I.

${ }^{\infty}$ (I9I6) 273 I11. 286, I12 N. E. 670

'0 See note 60 supra. 
rule, that the intention as to whether the covenant shall run is to be ascertained from the whole instrument, ${ }^{71}$ it seems plain that the rule of construction declared by the second resolution is on the defensive and may ultimately be overthrown altogether.

Another proof that the rule of construction declared by the second resolution is to be avoided rather than enforced is the readiness of many courts to discover some language in the covenant which is broad enough to include and bind assigns. Even Spencer's Case does not require that the word "assigns" be employed as a word of art ; ${ }^{72}$ the second resolution requires only that assigns be bound by "express words." Thus, a provision that the words "lessor" and "lessee" shall be held to include the "assigns" of each is enough. ${ }^{73}$ The use of the word "assigns" in another covenant, ${ }^{74}$ or in the habendum clause $^{75}$ of a lease for fifty years, has been held sufficient. So, also, the words "heirs, executors and administrators"76 or "lessor and those claiming under him" "legal representatives" 78 have all been held to be broad enough to include "assigns," while several cases have collected from the entire lease the intent that a covenant whose subject matter was not in being should run, although neither the word "assigns" nor any equivalent words were employed. ${ }^{79}$ These cases are a further illustration that modern courts are astute to avoid the rule of construction laid down by the second resolution, if they have adequate reason to believe that that rule would defeat rather than effectuate the intent of the parties to the lease.

\footnotetext{
${ }^{31}$ See note 59 supra.

"Assigns" is not a word of art like "heirs" in a deed. Sexauer v. Wilson (I907) I36 Iowa, 357, 363, II3 N. W. 94I; Masury v. Southworth (r859) 9 Ohio St. 340, 35a.

${ }^{73}$ Clegg v. Hands (I890, C. A.) I. R. 44 Ch. Div. 503.

"In re Robert Stephenson Co. [1915] I Ch. 802, 807 .

${ }^{25}$ Hollywood v. First Parish (1906) 192 Mass. 269, 78 N. E. I24.

${ }^{7}$ Ankeny v. Richardson (xgII, C. C. A. 8th) I87 Fed. 550.

${ }^{7}$ Stockett v. Howard (I870) $34 \mathrm{Md}$. I2I.

${ }^{18}$ Douglaston Realty Co. v. Hess (1908) I24 App. Div. 508, 108 N. Y. Supp. r036; see also New York Mut. Life Ins. Co. v. Armstrong (1885) II7 U. S. 591, 597, 6 Sup. Ct. 877; Wilckens v. Wilckens (1914, C. C. A. 8th) 217 Fed. 508.

${ }^{70}$ Peters v. Stone (1906) I93 Mass. 179, 79 N.' E. 336; Northern T. Co. ข. Sityder (I896, C. C. A. 7th) 75 Fed. 34; Tuttle v. Leiter (I897, C. C. N. D. I11.) 82 Fed. 947 ; cf. also cases cited under note 6r supra.
} 